\title{
Preliminary Screening of Nutraceutical Potential of Fruit Pulp, Peel and Seeds from Annona Squamosa (L.) and Annona Muricata (L.) Growing in Coast Region of Kenya
}

\author{
Lenny Mwagandi Chimbevo ${ }^{1,}$, , Suliman Essuman² \\ ${ }^{1}$ Institute of Tropical Medicine and Infectious Diseases (ITROMID), College of Health Sciences, School of Biomedical Sciences, Jomo \\ Kenyatta University of Agriculture and Technology (JKUAT), Nairobi, Kenya \\ ${ }^{2}$ Department of Medical Microbiology, Medical School, Mount Kenya University, Thika, Kenya
}

Email address:

clennyson@gmail.com (L. M. Chimbevo)

${ }^{*}$ Corresponding author

\section{To cite this article:}

Lenny Mwagandi Chimbevo, Suliman Essuman. Preliminary Screening of Nutraceutical Potential of Fruit Pulp, Peel and Seeds from Annona Squamosa (L.) and Annona Muricata (L.) Growing in Coast Region of Kenya. American Journal of BioScience.

Vol. 7, No. 3, 2019, pp. 58-70. doi: 10.11648/j.ajbio.20190703.11

Received: March 6, 2019; Accepted: May 5, 2019; Published: September 29, 2019

\begin{abstract}
An evaluation of nutraceutical potential of fruit pulp, peel and seeds from Annona Squamosa (L.) and Annona Muricata (L.) was conducted. Ripe fresh fruits were collected from farms in Kilifi and Kwale Counties; Coast province of Kenya. They were air dried, powdered and then subjected to extraction with solvents of increasing polarity (hexane, ethyl acetate, methanol and water) for 48 hours, filtered and dried. Qualitative and quantitative phytochemical analysis and Proximate and nutritional composition analysis was performed using methods of Association of Analytical Chemists (AOAC). Experimental results were expressed as mean from parallel measurements analyzed using mean separation through Fischer least significance difference by GenStat program. Comparisons were done by means of unpaired Student's t-test and significance difference established by ANOVA at 95\% confidence level. Differences of $P<0.05$ were considered statistically significant. The study revealed presence of alkaloids, flavonoids, phenols and saponins in hexane, ethyl acetate, Methanolic and aqueous extracts. High amount of dry matter $(97.59 \pm 0.15 \mathrm{mg} / 100 \mathrm{~g})$, WWB moisture content $(82.38 \pm 1.61 \mathrm{mg} / 100 \mathrm{~g})$, DWB moisture content $(6.91 \pm 0.42 \mathrm{mg} / 100 \mathrm{~g})$, crude fat $(19.04 \pm 4.63 \mathrm{mg} / 100 \mathrm{~g})$, crude proteins $(44.01 \pm 6.93 \mathrm{mg} / 100 \mathrm{~g})$, crude fibre $(50.03 \pm 1.81 \mathrm{mg} / 100 \mathrm{~g})$, total carbohydrates $(38.24 \pm 2.18 \mathrm{mg} / 100 \mathrm{~g})$ and oil content $(48.57 \pm 2.07 \mathrm{mg} / 100 \mathrm{~g})$ were detected. Appreciable values of reducing sugar $(7.70 \pm 0.12 \mathrm{mg} / 100 \mathrm{~g})$, TSS $(19.67 \pm 1.47 \mathrm{mg} / 100 \mathrm{~g})$, ascorbic acid $(37.24 \pm 1.77 \mathrm{mg} / 100 \mathrm{~g})$, tocopherol $(29.66 \pm 1.07 \mathrm{mg} / 100 \mathrm{~g})$, TBA $(0.78 \pm 0.05 \mathrm{mg} / 100 \mathrm{~g})$ and ash content $(8.93 \pm 0.69 \mathrm{mg} / 100 \mathrm{~g})$ were observed. Reasonable amounts of potassium $(354.58 \pm 2.17 \mathrm{mg} / 100 \mathrm{~g})$, sodium $(843.38 \pm 16.25 \mathrm{mg} / 100 \mathrm{~g})$, Calcium $(857.16 \pm 6.39 \mathrm{mg} / 100 \mathrm{~g})$, Magnesium $(395.54 \pm 4.58 \mathrm{mg} / 100 \mathrm{~g})$ and Phosphorous $(146.30 \pm 4.02 \mathrm{mg} / 100 \mathrm{~g})$ were detected whereas trace amounts of Copper $(1.00 \pm 0.03 \mathrm{mg} / 100 \mathrm{~g})$, Iron $(3.58 \pm 0.12 \mathrm{mg} / 100 \mathrm{~g})$, Zinc $(0.46 \pm 0.04 \mathrm{mg} / 100 \mathrm{~g})$ and Selenium $(1.51 \pm 0.03 \mathrm{mg} / 100 \mathrm{~g})$ were detected. Fatty acid profile showed presence of saturated fatty acids (SFA); Caprylic (C8:0), Capric (C10:0) (C12:0), Myristic (C14:0), Lauric Palmitic (C16:0) and Stearic (C18:0), monounsaturated fatty acids (MUFA); Oleic (C18:1) and polyunsaturated fatty acids (PUFA); Linoleic (C18:2) and Linolenic (C18:3). The study concludes that the fruit pulp, peel and seeds from $A$. Squamosa and A. Muricata has potential to be utilized in nutraceutical industries.
\end{abstract}

Keywords: Nutraceutical Composition, A. Squamosa and A. Muricata, Pulp, Peel and Seeds

\section{Introduction}

Since the beginning of human evolution, plants have been important sources of nutrients and medicines. Thus to achieve the vision 2030 and millennium development goals
(MDGs), Kenya and other developing countries needs a reorientation on the sustainable use of their natural resources, particularly in this era of economic recession. This is to harness the abundant rich flora and fauna for an improved primary health care delivery and source raw materials for 
nutrition and medicine. Therefore, a growing request for plant based medicines, health products, pharmaceuticals, cosmetics, and food supplements have been of great interest by researchers worldwide. Plants in the Annonaceae family are tropical and subtropical trees, shrubs and lianas comprising of about 130 genera and more than 2300 species [1]. The Annonaceae family; A. squamosa; Linn (sugar apple) and A. muricata; Linn (soursop) are fruit trees native to Central America [2-5].

Different parts of Annonaceae family contain numerous bioactive substances; polyketides, acetogenins, alkaloids, terpenes, tannins and phenolic, flavonoids and oils responsible for the observed insecticidal, cytotoxic, genetoxic antitumoral, antifeedant, antibacterial, antihelminthic, immuno-suppressant, pesticidal, antidiabetics, antioxidant, hepatoprotective, chemo-preventive and antiprotozoal properties [6-14]. Traditionally, they have been used for the treatment of illnesses ranging from diarrhea and dysentery, cardiac problems, fainting, worm infections, constipation, hemorrhage, dysuria, fever, thirst, malignant tumors and tumor suppuration, ulcers and atonic dyspepsia as well as abortifacient, anti-vermin, acaricidal, insecticidal and larvicidal [15-20]. The soft and edible fruit pulp has been used as food and nutrition supplements and in traditional medicine and industrial products preparations in different parts of the world [6-7], [21-24] with different parts of the world having similar gastronomic habits [22-23], [25]. The fruits are possible contributors of the vitamins, mineral salts, fibres and bioactive compounds of diets and provided a delicate balance of food security to the populations in regions where they grow [7, 25].

The Kenyan population has used A. muricata and $A$. squamosa plants for long and are cultivated in several parts of Kenyan [25]. Compared with the major fruit and vegetables crops, the Kenyan varieties have been neglected in terms of research to understand their nutraceutical properties presumably because they are less commonly known fruits. This makes the fruit of $A$. muricata and $A$. squamosa good candidate in search for nutraceutical agents. Therefore, the present investigation was undertaken to study phytochemicals, proximate composition analysis and nutritional attributes of sugar apple and soursop fruits growing in the Coastal region of Kenya. This may have the impact of improving nutrition and health by strengthening complementary and alternative medicine besides providing base line for discovery of lead compounds in nutraceutical industries for synthesis new drugs and food supplements.

\section{Materials and Methods}

\subsection{Plant Material}

The ripe fresh fruits of $A$. muricata and $A$. squamosa were collected from farms in coast the province (Kilifi and Kwale Counties) of Kenya. The harvested fruits were washed with chlorinated water and then transported to the Centre for
Traditional Medicine and Drug Research (CTMDR) of Kenya Medical Research Institute (KEMRI) laboratories, Jomo Kenyatta University of Agriculture and Technology (JKUAT) in the Department of Food Science Technology, Food Biochemistry laboratories. In the laboratory, the fruits were refrigerated to retard aging due to ripening, undesired metabolic changes and respiration and spoilage due to invasion by bacteria, fungi and yeast. The fruits pulp and seeds were dried using a constant temperature and humidity chamber (Tokyo Thermo Tech Co. Ltd, Japan) set at $25^{\circ} \mathrm{C}$ and $95 \%$ relative humidity for easy grinding then grinded into fine powder using a grinding machine (Mitamura Riken, Kogyo Inc. Tokyo, Japan). The grinded fruits parts inform of powder were weighed using a top-loading balance, transferred into polythene bags and airtight container, sealed, and stored at $4^{\circ} \mathrm{C}$ until extraction.

\subsection{Plant Material and Extracts Preparation}

Aqueous extraction was carried out for peel, seeds and pulp as described [26], where $50 \mathrm{~g}$ of the sample was macerated in $100 \mathrm{~mL}$ sterile distilled water in a Warring blender for 10 minutes. The macerate was first be filtered through double layered muslin cloth and then centrifuged at $4000 \mathrm{~g}$ for $30 \mathrm{~min}$. The supernatant was then filtered through Whatman No.1 filter paper and sterilized at $120^{\circ} \mathrm{C}$ for 30 minutes. The extract was finally preserved aseptically in an airtight bottle at $5^{\circ} \mathrm{C}$ for later use. In Organic solvent extraction; the powdered plant materials were weighed and sequentially subjected to extraction with solvents of increasing polarity starting with $n$-hexane preceded by ethyl acetate and finally Methanol $(\mathrm{MeOH})$ for 48 hours each with occasional swirling to ensure thorough extraction. The extracts were decanted and filtered through Whatman filter paper and the macerate steeped in solvent again for $48 \mathrm{hrs}$. The extraction process was repeated twice and the filtrates combined and concentrated on a rotary vacuum evaporator (Bibby Sterilin Ltd, RE 100B, UK) under reduced pressure at a temperature of $50^{\circ} \mathrm{C}$ and packed and stored in an airtight bottles at $5^{\circ} \mathrm{C}$ for later use.

\subsection{Phytochemical Analysis}

The following phytochemicals were tested for their presence in the plant; tannins (Ferric chloride test, Lead acetate test and potassium dichromate test) [27], flavonoids ( $\mathrm{NaOH}$ test, Conc $\mathrm{H}_{2} \mathrm{SO}_{4}$ test, $\mathrm{NH}_{4} \mathrm{OH}$ test and Shinado's test) [28], saponins (Haemolytic test and $\mathrm{NaHCO}_{3}$ test) [29], terpenoids (Salkowski's test) [30], phenols (Ferric chloride test and Lead acetate test) [28], glycosides (Fehling's test, Kidde's test and Keller-Killain test) [30], anthraquinones [31], alkaloids (Mayer's test, Dragendroff's test and Wagner's test) [28], anthocyanins (Ammonium test) [32], steroids and cholesterol [32], coumarins [32], fixed oil and fats (Spot test) [32]. Also the following phytochemicals were quantified; phenolic compounds [33], Tannins [34], flavanoids, alkaloids, terpenoids, steroids and glycosides [28]. 


\subsection{Proximate and Nutritional Composition Analysis}

Moisture content; Dry Weight Based (DWB) and Wet Weight Based (WWB), titratable acidity (TBA), total solids (dry matter), total soluble solids (TSS) ash content, crude fat, crude protein, crude fibre, total carbohydrates, reducing sugar, oil content, fatty acid composition, ascorbic acid content and tocopherol content of the various parts of A. squamosa and $A$. muricata were determined using the methods of Association of Official Analytical chemist's (AOAC) [35] as described [36].

\subsection{Data Analysis}

The experimental results derived in the study were expressed as the mean from three parallel measurements analyzed using mean separation by GenStat program [37]. Mean separation was done through Fischer least significance difference. Comparisons between two treatments were done by means of unpaired Student's t-test and significance established by ANOVA at $95 \%$ confidence level.

\section{Results}

\subsection{Extraction of Phytochemicals from Plants}

A total of twenty-four (24) extracts were obtained from three different parts of the two plants (Pulp, peel and seeds). The percentage yields calculated from each of the extracts is presented in table Table 1. From the results it's clear that the methanolic extracts gave higher percentage yields followed by aqueous (water) and ethyl acetate extracts whereas the hexane extracts had the lowest percentage yields.

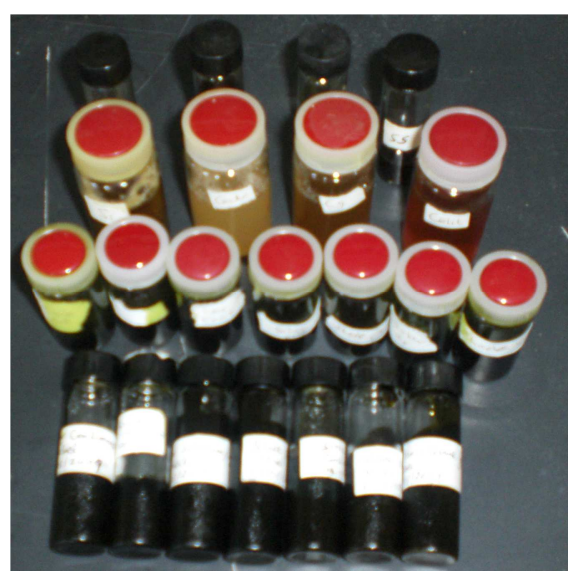

Figure 1. Methanol crude extracts of A. squamosa and A. muricata pulp, peel and seeds packed in airtight containers.

The appearances of the different extracts of the two plants from different parts of the fruit varied in consistency ranging from oily (ethyl acetate and $\mathrm{MeOH}$ ), caramelized (aqueous or water), pelleted (hexane) as indicated in Table 1 and Figure 1. The colour differed significantly ranging from deep colours (seeds and peels) to lightly colours (pulps) (Table 1and Figure 1). Further, in terms of consistency, the extracts were found to be sticky in the non-polar to not so polar solvents (Hexane and ethyl acetate) and non-sticky in the polar solvents (water and $\mathrm{MeOH}$ ).

Table 1. Percentage yield, colour and appearance of different crude extracts of A. squamosa and A. muricata pulp, peel and seeds.

\begin{tabular}{|c|c|c|c|c|c|}
\hline Plant & Part & Extract/Fraction & $\%$ Yield & Colour & Appearance \\
\hline $\mathrm{AS}$ & Seed & Hexane & $1.97 \pm 0.42$ & Blackish brown & Oily \\
\hline AS & Pulp & Hexane & $1.54 \pm 0.16$ & Yellowish brown & Oily \\
\hline AS & Peel & Hexane & $1.63 \pm 0.17$ & Greenish black & Oily \\
\hline AM & Seed & Hexane & $1.57 \pm 0.10$ & Blackish brown & Oily \\
\hline AM & Pulp & Hexane & $1.75 \pm 0.42$ & Yellowish brown & Oily \\
\hline AM & Peel & Hexane & $2.13 \pm 0.75$ & Greenish black & Oily \\
\hline AS & Seed & Ethyl Acetate & $2.55 \pm 0.49$ & Blackish brown & Caramel \\
\hline AS & Peel & Ethyl Acetate & $2.51 \pm 0.11$ & Greenish-White & Caramel \\
\hline AM & Seed & Ethyl Acetate & $2.56 \pm 0.36$ & Blackish brown & Caramel \\
\hline $\mathrm{AM}$ & Pulp & Ethyl Acetate & $2.87 \pm 0.27$ & Yellowish brown & Caramel \\
\hline AM & Peel & Ethyl Acetate & $2.23 \pm 0.39$ & Greenish & Caramel \\
\hline AS & Seed & $\mathrm{MeOH}$ & $25.54 \pm 1.67$ & Brownish & Caramel \\
\hline AS & Pulp & $\mathrm{MeOH}$ & $24.14 \pm 1.27$ & Brownish yellow & Caramel \\
\hline AS & Peel & $\mathrm{MeOH}$ & $25.06 \pm 1.09$ & Greenish white & Caramel \\
\hline AM & Pulp & $\mathrm{MeOH}$ & $28.69 \pm 1.48$ & Yellowish brown & Caramel \\
\hline AM & Peel & $\mathrm{MeOH}$ & $22.33 \pm 1.29$ & Blackish green & Caramel \\
\hline AS & Seed & Aqueous & $9.00 \pm 0.94$ & Blackish brown & Pellets \\
\hline AS & Pulp & Aqueous & $14.00 \pm 1.04$ & Light brown & Pellets \\
\hline AS & Peel & Aqueous & $6.00 \pm 0.87$ & Golden brown & Pellets \\
\hline AM & Seed & Aqueous & $7.00 \pm 1.33$ & Blackish brown & Pellets \\
\hline AM & Pulp & Aqueous & $7.00 \pm 1.05$ & Light brown & Pellets \\
\hline AM & Peel & Aqueous & $19.00 \pm 1.57$ & Blackish brown & Pellets \\
\hline
\end{tabular}

Mean values ( $\mathrm{n}=3) \pm$ SEM. Abbreviations: (AS) A. squamosa; (AM) A. muricata.

\subsection{Qualitative Phytochemical Screening}

The presence and/or absence of phytochemicals (Alkaloids,
Flavanoids, Glycosides, Anthocyanin, Saponins, Steroids, Tannin, Coumarins, Terpenoids and Phenols) in hexane, ethyl 
acetate, $\mathrm{MeOH}$ and aqueous extracts from pulp, peel and screening tests is presented in Table 2 and Table 3. seeds of $A$. squamosa and $A$. muricata using different

Table 2. Qualitative phytochemical components of A. squamosa plant parts.

\begin{tabular}{|c|c|c|c|c|c|c|c|c|c|c|c|c|c|}
\hline \multirow{2}{*}{ Phytochemical } & \multirow{2}{*}{ Test performed } & \multicolumn{3}{|c|}{ Aqueous } & \multicolumn{3}{|c|}{ Methanolic } & \multicolumn{2}{|c|}{ Hexane } & \multicolumn{4}{|c|}{ Ethyl acetate } \\
\hline & & Pulp & Seeds & Peel & Pulp & Seeds & Peel & Pulp & Seeds & Peel & Pulp & Seed & Peel \\
\hline \multirow{5}{*}{ Alkaloids } & General test & + & + & + & + & + & + & + & + & + & + & + & + \\
\hline & Tannic acid test & - & - & - & - & + & + & + & + & + & + & + & + \\
\hline & Meyer's test & - & - & + & + & + & + & + & + & + & + & + & + \\
\hline & Dragendroff's test & - & - & - & + & + & + & + & + & + & + & + & + \\
\hline & Wagner's test & - & - & + & + & + & + & + & + & + & + & + & + \\
\hline \multirow{3}{*}{ Flavanoids } & $\mathrm{NaOH}$ test & + & + & + & + & - & + & + & + & + & + & + & + \\
\hline & Shinado's test & + & + & + & + & + & + & + & + & + & + & + & + \\
\hline & $\mathrm{NH}_{4} \mathrm{OH}$ test & + & + & + & + & + & + & + & + & + & + & + & + \\
\hline \multirow{4}{*}{ Glycosides } & Fehling's test & - & - & - & - & + & - & + & + & - & + & + & - \\
\hline & Kedde test & - & - & - & - & + & - & + & + & - & + & + & - \\
\hline & Killer Killian test & + & + & + & + & + & - & + & + & - & + & + & + \\
\hline & Borntregar's test & + & + & + & + & + & - & + & + & - & + & + & + \\
\hline Phenols & Ferric chloride test & + & + & + & + & + & + & + & + & + & + & + & + \\
\hline Saponins & Hemolytic test & + & + & + & + & - & + & + & + & + & + & - & + \\
\hline \multirow{3}{*}{$\begin{array}{l}\text { Steroids } \\
\text { Fixed oils and } \\
\text { Fats }\end{array}$} & Libermann-Burchard test & + & + & - & + & + & + & + & + & + & + & + & + \\
\hline & Spot test & - & - & - & + & + & + & + & + & + & + & + & + \\
\hline & Ferric chloride test & + & + & - & + & + & - & + & + & - & + & + & - \\
\hline \multirow[t]{2}{*}{ Tannin } & Lead acetate test & + & + & - & + & + & - & + & - & - & + & + & - \\
\hline & Potassium dichromate & + & + & - & + & + & - & + & + & + & + & + & - \\
\hline Coumarins & & - & - & + & - & + & + & - & - & - & - & - & + \\
\hline Terpenoids & Salkowski's test & + & + & + & - & - & + & + & + & - & + & + & + \\
\hline Anthocyanin & Ammonia test & - & + & - & - & + & - & - & + & - & - & + & - \\
\hline Anthraquinones & & - & - & - & - & - & - & - & - & - & - & - & - \\
\hline
\end{tabular}

Key: $(+)=$ Present; $(-)=$ Absent

Table 3. Qualitative phytochemical components of A. muricata plant parts.

\begin{tabular}{|c|c|c|c|c|c|c|c|c|c|c|c|c|c|}
\hline \multirow{2}{*}{ Phytochemical } & \multirow{2}{*}{ Test performed } & \multicolumn{3}{|c|}{ Aqueous } & \multicolumn{3}{|c|}{ Methanolic } & \multicolumn{2}{|c|}{ Hexane } & \multicolumn{4}{|c|}{ Ethyl acetate } \\
\hline & & Pulp & Seeds & Peel & Pulp & Seeds & Peel & Pulp & Seeds & Peel & Pulp & Seed & Peel \\
\hline \multirow{5}{*}{ Alkaloids } & General Test & - & - & + & + & + & + & + & + & - & + & + & - \\
\hline & Tannic Acid & - & - & - & + & + & - & + & + & - & + & + & - \\
\hline & Meyer's test & - & - & + & + & + & + & + & - & - & + & + & - \\
\hline & Dragendroff's test & - & - & - & + & + & + & - & - & - & - & - & - \\
\hline & Wagner's test & - & - & + & + & + & + & - & - & - & - & - & - \\
\hline \multirow{4}{*}{ Flavonoids } & $\mathrm{NaOH}$ test & + & + & + & + & + & + & + & + & - & + & + & - \\
\hline & $\mathrm{H}_{2} \mathrm{SO}_{4}$ test & + & + & + & + & + & + & + & + & - & + & + & - \\
\hline & Shinado's test & + & + & + & + & + & + & + & + & - & + & + & - \\
\hline & $\mathrm{NH}_{4} \mathrm{OH}$ & + & + & + & + & + & + & + & + & - & + & + & - \\
\hline \multirow{4}{*}{ Glycosides } & Fehling's test & - & - & + & - & + & + & + & + & + & + & + & + \\
\hline & Kedde test & - & - & - & - & + & - & + & + & - & + & + & - \\
\hline & Killer Killian test & + & + & - & + & + & + & + & + & - & + & + & - \\
\hline & Borntregar's test & + & + & + & + & + & + & + & + & + & + & + & + \\
\hline \multirow{2}{*}{ Phenolic compounds } & Ferric chloride test & + & + & + & + & + & + & + & + & + & + & + & + \\
\hline & Lead acetate test & + & + & + & + & + & + & + & + & + & + & + & + \\
\hline \multirow{2}{*}{ Saponins } & $\mathrm{NaHCO}_{3}$ test & + & + & + & + & - & + & + & + & - & + & - & - \\
\hline & Hemolytic test & + & + & + & + & + & + & + & + & - & + & + & - \\
\hline Steroids & Salkowski's test & - & - & - & - & - & - & + & + & + & + & + & + \\
\hline Fixed oils and Fats & Spot test & - & - & - & - & - & - & + & + & + & + & + & + \\
\hline \multirow{3}{*}{ Tannin } & Ferric chloride test & + & + & + & + & + & + & + & + & + & + & + & + \\
\hline & Lead acetate test & + & + & + & + & + & + & + & - & + & + & + & + \\
\hline & $\begin{array}{l}\text { Potassium } \\
\text { dichromate }\end{array}$ & + & - & + & + & - & + & - & - & + & - & - & + \\
\hline Coumarins & & - & - & - & - & - & - & - & - & - & - & - & - \\
\hline Terpenoids & Salkowski's test & - & + & - & - & + & - & - & + & + & - & + & + \\
\hline Anthocyanin & Ammonia test & + & + & + & - & - & - & - & + & + & - & + & + \\
\hline Anthraquinones & & - & - & - & - & - & - & - & - & - & - & - & - \\
\hline
\end{tabular}

Key: $(+)=$ Present; $(-)=$ Absent. 


\subsection{Quantitative Phytochemical Screening}

The quantities of the identified phytochemicals obtained in this study are presented in Table 4. There was no significant difference $(P>0.05)$ between the phytochemical contents of the pulps and seeds in the two fruit species. However, the phytochemical contents between pulps and seeds within a species significantly differed $(p<0.05)$. The pulps had significantly higher content of phenols, flavonoids, tannins and alkaloids than the seeds. Further, phenols, saponins, flavonoids and tannins contents in the pulp of A. muricata were significantly higher than in $A$. squamosa with the opposite relationship observed in the seeds. However, the seeds of A. squamosa had higher content of phenols $(118.23 \pm 2.38 \mathrm{mg} / 100 \mathrm{~g})$. Low content of glycosides, terpenoids and steroids were observed in pulp and seeds. However, the seeds of $A$. squamosa had appreciable quantity of terpenoids $(19.04 \pm 0.05 \mathrm{mg} / 100 \mathrm{~g})$.

Table 4. Quantitative phytochemical analysis of different parts of different Annonaceae fruit species.

\begin{tabular}{|c|c|c|c|c|c|c|}
\hline \multirow{3}{*}{ Phytochemical } & \multicolumn{6}{|c|}{ Phytochemical concentration in different plant part and species (DWB) } \\
\hline & \multicolumn{3}{|c|}{ A. squamosa } & \multicolumn{3}{|l|}{ A. muricata } \\
\hline & Pulp & Peel & Seed & Pulp & Peel & Seeds \\
\hline Alkaloids & $14.69^{\mathrm{c}} \pm 0.32$ & ND & $7.69^{b} \pm 0.32$ & $2.34^{\mathrm{a}} \pm 0.12$ & ND & $23.43^{\mathrm{d}} \pm 0.60$ \\
\hline Flavonoids & $26.06^{\mathrm{a}} \pm 0.60$ & ND & $48.31^{\mathrm{b}} \pm 1.07$ & $178.70^{\mathrm{d}} \pm 1.98$ & ND & $80.69^{c} \pm 1.78$ \\
\hline Phenols & $3.71^{\mathrm{b}} \pm 0.27$ & ND & $118.23^{\mathrm{c}} \pm 2.38$ & $111.82^{\mathrm{d}} \pm 1.75$ & ND & $45.08^{\mathrm{b}} \pm 1.16$ \\
\hline Saponins & $6.05^{\mathrm{a}} \pm 0.24$ & ND & $9.56^{\mathrm{b}} \pm 0.31$ & $0.61^{\mathrm{c}} \pm 0.08$ & ND & $4.77^{\mathrm{d}} \pm 0.10$ \\
\hline Tannins & $30.52^{\mathrm{d}} \pm 5.03$ & ND & $16.86^{\mathrm{c}} \pm 0.63$ & $63.63^{\mathrm{b}} \pm 1.86$ & ND & $1.14^{\mathrm{a}} \pm 0.03$ \\
\hline Terpenoids & $5.87^{\mathrm{b}} \pm 0.04$ & ND & $19.04^{\mathrm{a}} \pm 0.05$ & $4.87^{\mathrm{b}} \pm 0.77$ & ND & $6.57^{\mathrm{b}} \pm 1.24$ \\
\hline Steroids & $0.46^{\mathrm{a}} \pm 0.03$ & ND & $0.26^{\mathrm{b}} \pm 0.03$ & $0.49^{\mathrm{a}} \pm 0.67$ & ND & $0.44^{\mathrm{a}} \pm 0.08$ \\
\hline
\end{tabular}

Mean values $(n=3) \pm$ SEM. Values appended by different small letters within a row are significantly different $(P<0.05)$. (ND) - Not done.

\subsection{Preliminary Proximate Compositional Analysis}

Preliminary proximate compositional analysis revealing the percentages of dry mater, ash content, moisture content, crude fiber, crude protein, crude fats and carbohydrates, reducing sugars, TSS and TBA are presented in Table 5 . The dry matter, moisture content (WWB and DWB), ash content and crude proteins in different parts of the two fruits did not differ significantly $(P>0.05)$ however, a significant difference $(\mathrm{P}<0.05)$ was observed between different parts. $A$. squamosa peel $(97.95 \pm 0.15 \mathrm{mg} / 100 \mathrm{~g})$, A. squamosa pulp
$(6.91 \pm 0.42 \mathrm{mg} / 100 \mathrm{~g})$ and $A$. squamosa pulp $(8.93 \pm 0.96$ $\mathrm{mg} / 100 \mathrm{~g}) \quad A$. muricata seeds $\quad(44.01 \pm 6.93 \quad \mathrm{mg} / 100 \mathrm{~g})$ respectively. The fiber content, crude fats, oil content, carbohydrates, reducing sugars, TSS, TBA, ascorbic acid and tocopherol differed significantly $(\mathrm{P}<0.05)$ between the two fruits and also in the different parts of the fruits (Table 5). Crude fats and oil contents significantly high in the seeds, carbohydrates, reducing sugars, TBA, ascorbic acid and tocopherol were significantly high in the pulps whereas TSS was significantly high in in the pulps (Table 5).

Table 5. Proximate composition analysis of different Annonaceae fruits pulp, peel and seeds.

\begin{tabular}{|c|c|c|c|c|c|c|}
\hline \multirow{3}{*}{ Parameter } & \multicolumn{6}{|c|}{ Proximate percentage composition $(\mathrm{mg} / \mathbf{1 0 0 g})$} \\
\hline & \multicolumn{3}{|c|}{ A. squamosa } & \multicolumn{3}{|l|}{ A. muricata } \\
\hline & Pulp & Seeds & Peel & Pulp & Seeds & Peel \\
\hline Dry matter $(\%)$ & $94.51^{\mathrm{a}} \pm 0.82$ & $95.31^{\mathrm{b}} \pm 0.01$ & $97.59^{c} \pm 0.15$ & $93.09^{\mathrm{a}} \pm 0.42$ & $94.94^{\mathrm{b}} \pm 0.80$ & $95.08^{\mathrm{c}} \pm 0.23$ \\
\hline Moisture (WWB) & $82.38^{\mathrm{b}} \pm 1.61$ & $70.02^{\mathrm{a}} \pm 0.17$ & $42.38^{\mathrm{b}} \pm 1.61$ & $82.38^{\mathrm{b}} \pm 1.61$ & $81.09^{\mathrm{b}} \pm 0.67$ & $41.02^{\mathrm{c}} \pm 0.70$ \\
\hline Moisture (DWB) & $5.49^{\mathrm{b}} \pm 0.82$ & $4.69^{b} \pm 0.01$ & $2.41^{\mathrm{a}} \pm 0.15$ & $6.91^{c} \pm 0.42$ & $5.06^{\mathrm{b}} \pm 0.80$ & $4.91^{\mathrm{b}} \pm 0.22$ \\
\hline Ash content & $2.92^{\mathrm{b}} \pm 0.31$ & $3.02^{\mathrm{b}} \pm 0.40$ & $2.88^{\mathrm{b}} \pm 1.75$ & $8.93^{c} \pm 0.69$ & $0.89^{\mathrm{a}} \pm 1.57$ & $2.96^{\mathrm{b}} \pm 0.93$ \\
\hline Crude Protein & $26.25^{\mathrm{b}} \pm 2.15$ & $31.28^{\mathrm{c}} \pm 5.31$ & $4.36^{\mathrm{a}} \pm 0.66$ & $35.04^{\mathrm{b}} \pm 3.18$ & $44.01^{\mathrm{c}} \pm 6.93$ & $3.75^{\mathrm{a}} \pm 0.98$ \\
\hline Fiber content & $43.84^{\mathrm{c}} \pm 4.12$ & $38.69^{\mathrm{a}} \pm 13.83$ & $52.20^{\mathrm{b}} \pm 1.10$ & $72.95^{\mathrm{c}} \pm 0.86$ & $40.48^{\mathrm{a}} \pm 1.21$ & $50.03^{\mathrm{b}} \pm 1.81$ \\
\hline Crude Fat & $4.30^{\mathrm{a}} \pm 0.39$ & $19.04^{\mathrm{b}} \pm 4.63$ & $4.08^{\mathrm{a}} \pm 0.33$ & $1.89^{\mathrm{a}} \pm 0.62$ & $17.83^{\mathrm{b}} \pm 9.49$ & $4.99^{\mathrm{a}} \pm 2.01$ \\
\hline Oil Content & $26.13 \pm 1.05$ & $39.12 \pm 2.58$ & $18.58 \pm 1.87$ & $33.67 \pm 1.97$ & $48.57 \pm 2.07$ & $25.97 \pm 1.48$ \\
\hline Carbohydrate & $38.24^{\mathrm{a}} \pm 2.18$ & $29.88^{\mathrm{b}} \pm 1.63$ & $36.62^{\mathrm{c}} \pm 1.43$ & $2.42^{\mathrm{d}} \pm 0.88$ & $30.68^{\mathrm{b}} \pm 6.92$ & $32.19^{\mathrm{c}} \pm 4.00$ \\
\hline Reducing sugars & $7.70^{\mathrm{c}} \pm 0.12$ & $0.35^{\mathrm{d}} \pm 0.77$ & $0.19^{\mathrm{a}} \pm 0.12$ & $3.13^{\mathrm{e}} \pm 1.01$ & $0.17^{\mathrm{a}} \pm 0.02$ & $0.57^{\mathrm{b}} \pm 0.05$ \\
\hline Total soluble solids (TSS) & $16.77^{\mathrm{d}} \pm 0.09$ & $19.67^{\mathrm{c}} \pm 1.47$ & $28.16^{\mathrm{a}} \pm 2.47$ & $7.21^{\mathrm{e}} \pm 1.67$ & $17.58^{\mathrm{d}} \pm 1.08$ & $26.57^{\mathrm{ab}} \pm 1.23$ \\
\hline Titratable acidity & $0.18^{\mathrm{a}} \pm 0.01$ & $0.05^{\mathrm{b}} \pm 0.01$ & $0.01^{\mathrm{c}} \pm 0.00$ & $0.78^{\mathrm{d}} \pm 0.05$ & $0.21^{\mathrm{a}} \pm 0.01$ & $0.09^{\mathrm{e}} \pm 0.01$ \\
\hline Ascorbic acid & $19.60^{\mathrm{a}} \pm 2.77$ & $13.75^{\mathrm{c}} \pm 0.17$ & ND & $37.24^{\mathrm{b}} \pm 1.77$ & $21.85^{\mathrm{a}} \pm 0.04$ & ND \\
\hline Tocopherol & $17.42^{\mathrm{a}} \pm 1.25$ & $10.15^{\mathrm{c}} \pm 0.13$ & ND & $29.66^{\mathrm{b}} \pm 1.07$ & $16.55^{\mathrm{a}} \pm 0.19$ & ND \\
\hline
\end{tabular}

Mean values $(n=3) \pm$ SEM. Means with different superscript letters within a row are significantly different $(\mathrm{P}<0.05)$.

\subsection{Fatty Acid Composition}

The fatty acid profile of $A$. squamosa and $A$. muricata fruit pulp and seeds showed the presence of saturated fatty acids
(SFA), Caprylic (C8:0), Capric (C10:0) (C12:0), Myristic (C14:0), Lauric Palmitic (C16:0) and Stearic (C18:0), monounsaturated fatty acids (MUFA); Oleic (C18:1) and polyunsaturated fatty acids (PUFA); Linoleic (C18:2) and 
Linolenic (C18:3) as presented in Table 6. Unsaturated fatty acids (USFA) were significantly in higher amounts than the SFA attributed to the presence of high contents of the three USFA; linoleic acid, linolenic acid and oleic acid. Linoleic acid was the major PUFA whereas oleic acid was the major MUFA with significantly higher values in seeds. The predominant SFA was palmitic acid with $457.73 \pm 30.16$ $\mathrm{mg} / 100 \mathrm{~g}$ and $349.18 \pm 14.31 \mathrm{mg} / 100 \mathrm{~g}$ in pulp and seeds respectively. However, A. muricata seeds and A. muricata pulp was composed of high amounts of total fatty acids, whereas A. squamosa seeds and A. squamosa pulp had significantly lower $(P<0.05)$ amounts of the fatty acids.

Table 6. Fatty acid composition of the Annonaceae fruits pulp and seeds.

\begin{tabular}{llll}
\hline \multirow{2}{*}{ Fatty acid } & \multicolumn{3}{l}{ Plant sample Percentage fatty acid content $(\mathbf{m g} / \mathbf{1 0 0 g}$ DWB) } \\
\cline { 2 - 4 } & \multicolumn{1}{c}{ A. muricata } & A. squamosa \\
\cline { 2 - 4 } & Pulp & Seed & Pulp \\
\hline Caprylic (C8:0) & $0.01^{\mathrm{c}} \pm 0.00$ & $21.46^{\mathrm{a}} \pm 5.81$ & $5.87^{\mathrm{b}} \pm 0.24$ \\
Capric (C10:0) & $8.21^{\mathrm{a}} \pm 0.83$ & $1.67^{\mathrm{b}} \pm 0.14$ & $0.84^{\mathrm{b}} \pm 0.09$ \\
Lauric (C12:0) & $3.53^{\mathrm{ab}} \pm 1.46$ & $5.13^{\mathrm{a}} \pm 0.27$ & $2.46^{\mathrm{b}} \pm 0.32$ \\
Myristic (C14:0) & $90.14^{\mathrm{b}} \pm 8.01$ & $211.47^{\mathrm{a}} \pm 3.65$ & $34.94^{\mathrm{c}} \pm 0.40$ \\
Palmitic (C16:0) & $457.73^{\mathrm{a}} \pm 30.16$ & $349.18^{\mathrm{b}} \pm 14.31$ & $208.01^{\mathrm{c}} \pm 7.03$ \\
Stearic (C18:0) & $37.67^{\mathrm{b}} \pm 5.93$ & $34.27^{\mathrm{b}} \pm 0.41$ & $10.51^{\mathrm{a}} \pm 1.76$ \\
Linoleic (C18:2) & $372.45^{\mathrm{b}} \pm 24.34$ & $500.16^{\mathrm{a}} \pm 17.12$ & $18.47^{\mathrm{c}} \pm 0.08$ \\
Linolenic (C18:3) & $100.12^{\mathrm{b}} \pm 2.39$ & $196.67^{\mathrm{a}} \pm 17.82$ & $80.13^{\mathrm{d}} \pm 3.16$ \\
Oleic (C18:1) & $38.65^{\mathrm{b}} \pm 6.97$ & $75.08^{\mathrm{a}} \pm 7.83$ & $67.33^{\mathrm{c}} \pm 10.03$ \\
\hline
\end{tabular}

Mean values $(\mathrm{n}=3) \pm$ SEM. Means with different small letters within a row are significantly different $(P<0.05)$.

\subsection{Mineral Elements Composition}

The pulp and seeds of A. muricata and A. squamosa revealed the presence of different minerals elements (Table 7 and Figure 2). The different parts of different species analyzed revealed reasonable amounts of potassium, sodium, Calcium, Magnesium and Phosphorous. Other mineral elements were detected in trace amounts and included Copper, Iron, Zinc and Selenium. The general trend was that there were significant differences $(\mathrm{p}<0.05)$ in Sodium, Potassium, Magnesium, Phosphorous, Copper, Iron, Zinc and
Selenium concentration between the analyzed species. The concentration of Calcium differed significantly $(p<0.05)$ between the species analyzed. However, a variation in mineral elements concentration was evident between the pulp and the seeds $(p<0.05)$. Significantly higher concentration of most the identified mineral elements analyzed was recorded in the seeds than in the pulp in A. squamosa while the pulp of $A$. muricata fruit had higher mineral element concentration than the seeds.

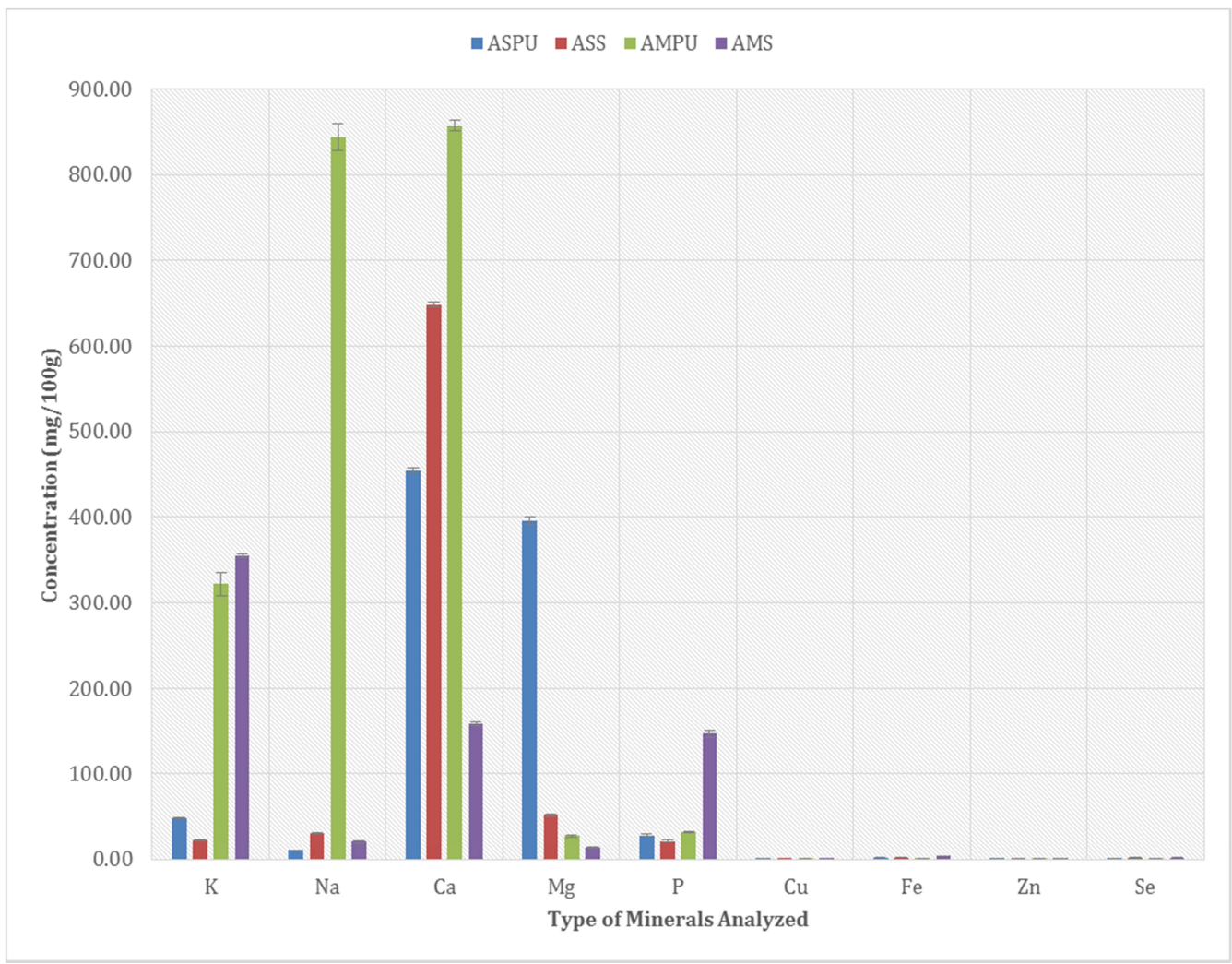

Figure 2. Mineral composition in the fruit palp and seeds of A. squamosa and A. muricata. 
Table 7. Mineral composition of different parts of A. squamosa and A. muricata fruits.

\begin{tabular}{|c|c|c|c|c|c|c|}
\hline \multirow{3}{*}{ Mineral } & \multicolumn{6}{|c|}{ Mineral concentration (mg/100g DWB) } \\
\hline & \multicolumn{3}{|c|}{ A squamosa } & \multicolumn{3}{|l|}{ A. muricata } \\
\hline & Pulp & Peel & Seeds & Pulp & Peel & Seeds \\
\hline $\mathrm{K}$ & $48.03^{\mathrm{a}} \pm 0.60$ & $\mathrm{ND}$ & $23.31^{\mathrm{a}} \pm 0.73$ & $322.25^{\mathrm{b}} \pm 13.11$ & ND & $354.58^{\mathrm{b}} \pm 2.17$ \\
\hline $\mathrm{Na}$ & $10.41^{\mathrm{a}} \pm 0.41$ & ND & $31.39^{\mathrm{a}} \pm 0.56$ & $843.38^{\mathrm{b}} \pm 16.25$ & ND & $20.99^{\mathrm{b}} \pm 1.35$ \\
\hline $\mathrm{Ca}$ & $454.96^{\mathrm{c}} \pm 2.88$ & ND & $648.52^{\mathrm{c}} \pm 2.48$ & $857.16^{\mathrm{b}} \pm 6.39$ & ND & $158.37^{\mathrm{b}} \pm 2.89$ \\
\hline $\mathrm{Mg}$ & $395.54^{\mathrm{c}} \pm 4.58$ & ND & $52.00^{\mathrm{c}} \pm 1.01$ & $24.00^{\mathrm{a}} \pm 0.77$ & ND & $13.71^{\mathrm{a}} \pm 0.34$ \\
\hline $\mathrm{P}$ & $28.71^{b} \pm 0.99$ & ND & $22.20^{\mathrm{b}} \pm 0.81$ & $32.50^{\mathrm{c}} \pm 0.94$ & ND & $146.30^{\mathrm{a}} \pm 4.02$ \\
\hline $\mathrm{Cu}$ & $0.10^{\mathrm{a}} \pm 0.00$ & ND & $0.03^{\mathrm{a}} \pm 0.00$ & $1.00^{c} \pm 0.03$ & ND & $0.04^{\mathfrak{c}} \pm 0.00$ \\
\hline $\mathrm{Fe}$ & $1.65^{\mathrm{a}} \pm 0.04$ & ND & $2.07^{\mathrm{a}} \pm 0.02$ & $1.05^{\mathrm{b}} \pm 0.06$ & ND & $3.58^{\mathrm{b}} \pm 0.12$ \\
\hline $\mathrm{Zn}$ & $0.32^{\mathrm{a}} \pm 0.02$ & ND & $0.31^{\mathrm{a}} \pm 0.02$ & $0.40^{\mathrm{b}} \pm 0.03$ & ND & $0.46^{b} \pm 0.04$ \\
\hline $\mathrm{Se}$ & $0.87^{\mathrm{a}} \pm 0.01$ & ND & $1.46^{\mathrm{a}} \pm 0.04$ & $0.79^{\mathrm{a}} \pm 0.07$ & ND & $1.51^{\mathrm{a}} \pm 0.03$ \\
\hline
\end{tabular}

Means values (3) \pm SEM. Means with different superscript letters within a row are significantly different $(\mathrm{P}<0.05)$; ND - Not done.

\section{Discussion}

\subsection{Extraction, Qualitative and Quantitative Phytochemical Screening}

The yields in dry extracts ranged between $1.54 \pm 0.16 \%$ and $28.69 \pm 1.48$, depending on the solvent used. However, the percentage yield may vary depending on the species of the fruit and the technique used for the extraction [38]. From this study, it can be demonstrated from the results that the methanol extracts gave the highest yields while the hexane extracts had the lowest yields which is in line with past works in which methanolic extracts are preferred due to their high yield in extraction processes [39]. Water extraction naturally sets some limitations to the amount of compounds that can be extracted due to its polarity [40]. Observations of the structure and forms showed that the methanol extracts were in form of caramel as they were gluey because of the sugar content extracted by methanol [39]. The hexane extracts, which gave the least yield, were oily while the aqueous extracts were dry and pelleted a result that is in agreement with other studies [39]. Colours of the extracts ranged from green, yellow to brown. Peel extracts had the deepest colours followed by that of seeds while that of pulps were light coloured. The phytochemicals tested included tannins, flavonoids, saponins, terpenoids, phenols, glycosides, alkaloids, anthocyanins, steroids and cholesterol, coumarins, fixed oil and fats. However, anthraquinones were absent, a finding that is in agreement with other studies [9], [41-44]. Due to the presence different phytochemicals at a relatively higher amount as a result of their wild nature [25], $A$. muricata and $A$. squamosa have the potential to act as a source of useful drugs.

Free radical scavenging (antioxidant), antimicrobial, antiviral and anti-inflammatory anticarcinogenic, immunostimulant properties of plant extracts have been associated with the presence of tannins and saponins [32, 45]. Detection of tannins and saponins in harmony with other studies [46-47] is an indication of the potential health benefits of these fruits to cure a number of diseases. Saponins and tannins impart astringent and bitter taste to plant-based foods making them undesirable when present in very high quantities in ready-to-eat foods such as fruit [46] while identified types of saponins have been associated with adverse effects on fishes and other aquatic lives [48]. However, the current study indicates that the content of tannins and saponins of these fruits when ripe is just adequate thereby eroding any cause for alarm in the consumption of these fruits.

Glycosides were detected confirming reports by other studies [47, 49]. The study also showed negative inferences to various tests for alkaloids in the pulp, results that are in accordance with other reports published elsewhere [49]. The presence of glycosides indicates existence of compounds with pharmacologically active genins and at least one reducing sugar [32]. The absence of glycosides is desired due to toxicity associated with their intake [49]. However, reported minute amounts and their relaxant and calming effects on the heart and muscles when consumed in small doses [50] suggest use of these fruits in human diet. The presence of glycosides in these fruits is much desired due to their importance of some specific glycosides such as cardiac glycosides in treating congestive heart failure [51]. Moreover, the findings support reviewed literature and studies on the potential of these fruits in the treatment of cardiac-related ailments as used in folkloric medicine [51-52].

Flavonoids are acclaimed for antioxidant and antimicrobial activities [52] while coumarins are anti-stress compounds postulated to have antiviral and anticoagulant activities [32]. Positive and negative inferences for coumarins were obtained in pulp, peel and seeds for A. muricata and A. squamosa respectively. Their detection corroborates earlier findings in species from other countries [47-48]. However, coumarins are not usually assessed in the phytochemical analysis of most fruits resulting in limited data [32]. Terpenoids are responsible for wound healing properties leading to wound contraction and epithelialization [53], a potential that makes their presence in foods desirable. General test for terpenoids gave negative inferences for the pulp of $A$. muricata. Although terpenoids were detected in $A$. squamosa in this study, the data in its detection is scarce [32]. Some samples, which tested positive to terpenoids, had a negative inference for the sterols, which confirms the hypothesis that all sterols are terpenoids, but the vice-versa is untrue [32]. The detection of terpenoids in the samples further indicates the medicinal potential of the edible portions of the studied fruits. 
An inverse relationship exists between intake of plant sterol and risk of some cancers [54]. The detection of this plant chemical therefore, suggests the potential health benefits associated with the consumption of these fruits. Phenolic compounds are plant secondary metabolites, which constitute one of the most common and widespread groups of compounds in plants [55]. Plants need phenolic compounds for pigmentation, growth, reproduction, resistance to diseases and many other functions [55]. Fruits of different genotypes of Annona species were studied for phenol content [47], [5658], [69]. Above result indicated that A. muricata which possessed significantly higher phenol content can be a potential source of disease resistance and also for therapeutic purpose in pharmaceuticals.

\subsection{Proximate and Nutritional Composition Analysis}

The nutrient concentration in plant material expressed on a dry matter basis is a function of the speed rate of nutrient uptake and dry mass accumulation [60]. There is an increasing demand and scientific awareness on nutritional and functional properties of oils and fats, proteins and amino acids and minerals, carbohydrates and phytochemicals. Therefore, proximate and nutrition compositional analysis of edible fruits is a current focus of international research. One of the targets of this study was to perform proximate and nutrition composition analysis of pulp, peel and seeds from A squamosa and A. muricata fruits. Moisture content of foods gives an indication of available dry matter and plays a major role in determining the propensity of the food to spoil [61]. The high moisture content of fresh pulp peel and seeds was contributed by the bulk tissue weight of fleshy and succulent fruits. After oven drying, the moisture level reduced significantly. The high moisture content of these fruits provide a good source of raw materials for juice manufacturing as a supplement to whole fruits. However, it has been revealed that high moisture content tends in fruits tend to promote microbial contamination and chemical degradation [62]. Higher moisture content in fruits reduce natural product stability and shelf life making the perishable by providing a suitable medium for many reactions to occur. Analogous moisture content values have been obtained in other studies for all the samples [63-64] and heterologous results in some studies $[57,65]$ where the moisture content of A. muricata pulp was found to be significant high. Although moisture deficiency is essential for good quality and quantity of the yield, severe deficiency may lead to the death of plant [66]. The relatively more moisture content can be more beneficial as moisture content makes the fresh fruit juicier and more palatable to the consumer [67]. The high moisture content as observed in the Annona species pulp reflects perishability and short shelf life of the fruits [68]. The moisture content reduced significantly after drying indicating an increase in shelf life.

The organic matter content of a plant seed material is the measure of the total lipids, proteins and carbohydrates [69]. The results from this study indicate that the pulp and seeds of the three Annonaceae plants can be described as having high nutritional value. In the pulp, protein content was in the range $26.25 \pm 2.15 \mathrm{mg} / 100 \mathrm{~g}$ (A. squamosa) to $35.04 \pm 3.18 \mathrm{mg} / 100 \mathrm{~g}$ (A. muricata), results that are in agreement with other studies $[58,66]$. In the seeds, the protein content was in the ranges of $31.28 \pm 5.31 \%$ (A. muricata) to $44.01 \pm 6.93 \mathrm{mg} / 100 \mathrm{~g}$ (A. squamosa). Generally, the fruits had protein contents comparatively higher than literature values for some common fruits [70]. Lower values have been reported [58] which could be again due to environmental factors. Since proteins are the building block of the body and are important components of various enzymes and nucleic acid good amount of proteins are required in our daily diet [71]. The results of this study suggest that the fruits of $A$. squamosa and $A$. muricata can be good source of proteins in consumer's diet.

Carbohydrates serve organisms as energy sources and as essential structural component of nucleic acid that stores genetic information. The pulp of $A$. squamosa recorded significantly higher amount of total carbohydrates $(38.24 \pm 2.18 \mathrm{mg} / 100 \mathrm{~g})$ compared to significantly lower amount of total carbohydrates recorded for A. muricata pulp $(2.42 \pm 0.88 \mathrm{mg} / 100 \mathrm{~g})$. These values of carbohydrates are fairly good and may be considered of nutritional significance. The experimental results from this study therefore reveal that the pulp of $A$. squamosa is a potential source of energy and can be included in the diet. The reducing sugars measured in A. squamosa and A. muricata fruits pulp, peel and seeds were found to be in the range of $0.17 \pm 0.02 \mathrm{mg} / 100 \mathrm{~g}$ (A. muricata seeds) to $7.70 \pm 0.12 \mathrm{mg} / 100 \mathrm{~g}$ ( $A$. squamosa pulp). Maximum reducing sugars were recorded in $A$. squamosa, whereas minimum contents were recorded for $A$. muricata. From the results of this study, it can be concluded that $A$. squamosa contain significantly amount of reducing sugar used as a source of resistance against biotic stresses to the plant [66] besides being utilized by humans [71].

Further, the amount of sugars present in a plant play and important role in osmotic adjustment and in providing protection against various types of stresses [66]. This component of sugar is the TSS whose measured content in the fruit pulp, peel and seeds of $A$. squamosa and $A$. muricata was found in the range of $7.21 \pm 1.67 \mathrm{mg} / 100 \mathrm{~g}$ (A. muricata pulp) to $28.16 \pm 2.47 \mathrm{mg} / 100 \mathrm{~g}$ (A. muricata peel). The content of TSS in the pulp was found to be lower at $7.21 \pm 1.67$ $\mathrm{mg} / 100 \mathrm{~g}$ (A. muricata) and $16.77 \pm 0.09 \mathrm{mg} / 100 \mathrm{~g}$ (A. squamosa) compared to the seeds and peel. Titratable acidity content was estimated from A. squamosa and $A$. muricata fruit pulp, peel and seeds were in the range of $0.01 \mathrm{mg} / 100 \mathrm{~g}$ (A. squamosa peel) to $0.78 \pm 0.05 \mathrm{mg} / 100 \mathrm{~g}$ (A. muricata pulp). The maximum value of titratable acidity was found to be $0.78 \pm 0.05 \mathrm{mg} / 100 \mathrm{~g}$ (A. muricata) followed by $0.21 \pm 0.01$ $\mathrm{mg} / 100 \mathrm{~g}$ (A. muricata seeds) and $0.18 \pm 0.01 \mathrm{mg} / 100 \mathrm{~g}$ ( $A$. squamosa pulp). In contrast to other studies obtained slightly higher titratable acidity values of $0.79 \mathrm{mg} / 100 \mathrm{~g}$ (seeds) and $3.43 \mathrm{mg} / 100 \mathrm{~g}$ (pulp) [57] and $0.10-1.25 \mathrm{mg} / 100 \mathrm{~g}$ in freshly matured fruit of $A$. muricata [56]. Titratable acidity in fruits plays an important role in taste, color, and indicator of the quality and microbial stability of the fruit juice and 
determines maturity [57]. Due to appreciable levels of titratable acidity, A. squamosa and A. muricata fruits can have better acceptability for the consumers.

Crude fibre content of foods gives an indication of its dietary fibres [72]. Dietary fibers have a number of beneficial effects related to its indigestibility in the small intestine [7273]. As an important component of the diet, it enhances faecal bulk, prevents constipation, stimulating peristalsis and decreasing the risk of many disorders such as constipation, diabetes, cardiovascular diseases and obesity [73]. Fibre content measured in different parts of $A$. squamosa and $A$. muricata fruits were found to be in the range of $38.69 \pm 1383$ $\mathrm{mg} / 100 \mathrm{~g}$ (A. squamosa seeds) to $72.95 \pm 0.86 \mathrm{mg} / 100 \mathrm{~g}$ ( $A$. muricata pulp). These results were comparable with most other fruits seeds and pulps of their respective family [73]. From the results of present study, it can be concluded that $A$. squamosa and $A$. muricata contain relatively more fibres. Thus their inclusion in the diet can provide good roughage in the diet which can be more helpful for maintaining the health of the gastro-intestinal tract, weight regulation and thus decreasing the risk of many disorders. Considering the health benefits of dietary fibre as elaborated in other studies [72-73], the relatively high crude fibre content observed in the studied fruits is much desired.

Fats are important part of the diet because they are vital to the development of various organs and systems [74]. As a concentrated source of calories, especially in infants, fat helps to resolve the potential problems of high calorie needs and small stomach capacity $[71,75]$. However, the pulp of the Annonaceae fruits studied had low content of crude fat whereas seeds had a higher crude fat content. The study showed a considerable fat content in the studied varieties of Annonaceae fruits supporting studies on essential oils extraction from fresh fruits of $A$. muricata with potential for human health [53]. Therefore, the seeds of the three Annonaceae species analyzed can be a good source of lipids. Significantly higher oil content was obtained for $A$. muricata compared to $A$. squamosa. The result was not comparable with $26.8 \mathrm{mg} / 100 \mathrm{~g}$ oil content in the seeds of $A$. squamosa [76] and $22.2 \mathrm{mg} / 100 \mathrm{~g}$ in the seed kernels of $A$. squamosa [77]. The values of oil content $26.13 \pm 1.05 \mathrm{mg} / 100 \mathrm{~g}$ ( $A$. squamosa) and $33.67 \pm 1.97 \mathrm{mg} / 100 \mathrm{~g}$ (A. muricata) in the pulp are sufficient enough to cater for the needs in the diet. Therefore, Annona species could be very useful as a source of oil for both domestic and industrial uses because of the relatively high oil content. Instead of discarding them as waste they can be better utilized in oil industries and can also be used as cooking oil if it is deodorized.

The fatty acid profile shows both short and medium carbon chain SFA; Caprylic acid (C8:0), Capric acid (C10:0), Lauric acid (C12:0), Myristic (C14:0), Palmitic (C16:0) and Stearic (C18:0), MUFA; Oleic (C18:1) and PUFA; Linoleic (C18:2) and Linolenic (C18:3). Amongst the SFA, Palmitic acid was predominant, followed by Myristic, Stearic acid, Capric acid, Lauric acid and finally Caprylic acid in that order. This result is consistent with the fact that palmitic acid is the most abundant SFA in vegetable fats; Stearic acid being the least common while the others (Caprylic acid, Capric acid, Lauric acid, Myristic) exists as intermediates during fatty acids biosynthesis. Linoleic acid was the abundant PUFA compared to linolenic acid whereas oleic acid was the abundant MUFA [78-79]. The pulp and seeds of plants show significant amounts of essential fatty acid. However, the proportions of linoleic acid to linolenic acid may be different. The greater the amount of linoleic acid compared to linolenic may not desirable since linolenic acid is more susceptible to oxidation [78-79].

The ash content present in any food is generally recognized as a measure of quality for assessment of functional properties of foods [80]. The levels of total ash in A. squamosa and A. muricata were up to $8.93 \pm 0.69 \mathrm{mg} / 100 \mathrm{~g}$ (A. muricata pulp) in the dried parts of the plant. The levels of ash composition were higher than some of the common fruits such as avocado [81], papaya [82] and banana [83]. The ash content gives an approximate measure of total mineral elements composition of foods not withstanding contaminations, which may lead to higher than factual values [81]. Iron, copper, zinc, calcium, magnesium, phosphorous, sodium and potassium were detected in the pulp and seeds of the fruits. The study observed high content of calcium $(857.16 \pm 6.39 \mathrm{mg} / 100 \mathrm{~g}$ in A. muricata pulp), sodium (843.38 $\pm 16.25 \mathrm{mg} / 100 \mathrm{~g}$ in A. muricata pulp) and potassium (322.25 $\pm 13.11 \mathrm{mg} / 100 \mathrm{~g}$ in $A$. muricata pulp), magnesium (395.54 $\pm 4.58 \mathrm{mg} / 100 \mathrm{~g}$ in $A$. squamosa pulp) and phosphorous (146.30 $\pm 4.02 \mathrm{mg} / 100 \mathrm{~g}$ in $A$ muricata seeds) whereas iron, copper, zinc and selenium were detected in trace amounts. While sodium and potassium are important in the body fluid, calcium plays an essential role in bone formation and magnesium is involved in enhancement of activities of metabolic enzymes, zinc is critical to the normal functioning of the immune system [84]. Low $\mathrm{Na} / \mathrm{K}$ ratio is evident due to high content of potassium compared to sodium. Diets with low $\mathrm{Na} / \mathrm{K}$ ratio are of nutritional important since it is associated with lower incidence of hypertension [84]. Since calcium was found to be among the most abundant mineral element present, Annonaceae fruits can be considered an appropriate dietary source of calcium to maintain the biological role of nerve transmission, muscle contraction, glandular secretion as well as mediating vascular contraction and vasodilation [85]. It is significant that due to notable mineral elements content, the pulps and seeds of $A$. squamosa and A. muricata fruits can satisfy a substantial portion of the mineral elements requirement. The values of mineral elements obtained in this study were different from earlier studies performed in other regions of the world [47], [56-59]. The difference could be due to varietal differences, impact of type and composition of soil of fruit origin and time of the experiment $[58,86]$.

The study also indicates that Annonaceae species are appreciable source of tocopherol and ascorbic acid. The recommended daily intake (RDI) of ascorbic acid is about 30 $\mathrm{mg} /$ day for adults and $17 \mathrm{mg} /$ day for children [87, 83]. Ascorbic acid content was found in the range of 19.60 $\mathrm{mg} / 100 \mathrm{~g}$ to $39.24 \mathrm{mg} / 100 \mathrm{~g}$. Maximum content of ascorbic 
acid was recorded for $A$. muricata $(39.24 \mathrm{mg} / 100 \mathrm{~g})$ whereas minimum ascorbic acid content was recorded for $A$. squamosa $(19.60 \mathrm{mg} / 100 \mathrm{~g})$. The high values of ascorbic acid signify the potential use of the fruit as a good source of ascorbic acid. Studies conducted on sugar apple (sweetsop) and soursop fruits [47], [56-59], [65, 88] claimed almost the same value of ascorbic acid with the current study. Therefore, these fruits could be considered as good sources of ascorbic acid for purposes of human nutrition.

\section{Conclusions and Recommendations}

The present study on preliminary physicochemical and phytochemical screening of Annona squamosa could be used as the diagnostic tool for the standardization of medicinal plant. The constituents of fruit pulp, peel and seeds of $A$. squamosa and A. muricata may have several medicinal properties and can be utilized for the treatment of various diseases. The different parts (pulp, peel and seeds) of A. squamosa and A. muricata had appreciable amount of mineral content, crude fat, crude protein, crude fibre, total carbohydrates, reducing sugar, oil content, fatty acid, ascorbic acid and tocopherol. Further research on this species may help in the isolation of therapeutically potent compounds which can be finally be subjected to pharmacological activities, thus leading to opening up new avenues in the use of natural products for nutritional and therapeutic purposes.

\section{Authors' Contributions}

This work was carried out in collaboration between all authors. 'Authors LMC' designed the study, developed the protocol and performed the experimental analyses of the study. 'Authors SE' managed the literature searches and performed the statistical analysis and participated in the development of the first draft of the manuscript. The authors read and approved the final manuscript.

\section{Acknowledgements}

The Kenyan Government through National Commission for Science, Technology and Innovation (NACOSTI) in a Science; Technology and Innovation grant for Postgraduate studies Grant No. NACOSTI/RCD/ST\&I $5^{\text {th }}$ CALL PhD/066 is indebted for the support and funding to the study.

\section{References}

[1] Hotta M, Ogata K, Nitta A, Hoshikawa K, Yanagi M and Yamazaki K. Useful plants of the world, Heibonsha LTD, Tokyo. 1989.

[2] Leatemia JA and Isman MB. Toxicity and antifeedant activity of crude seed extracts of Annona squamosa (Annonaceae) against lepidopteran pests and natural enemies). International Journal of Tropical Insect Science, 2004; 24 (02): 150-158.
[3] Wu YC, Hung YC, Chang FR, Cosentino M, Wang HK and Lee KH. (Identification of ent-16ß, 17-dihydroxykauran-19oic acid as an anti-HIV principle and isolation of the new diterpenoids annosquamosins $\mathrm{A}$ and $\mathrm{B}$ from Annona squamosa). Journal of natural products, 1996; 59 (6): 635-637.

[4] Vithanage HIMV. Pollen-stigma Interactions: Development and Cytochemistry of Stigma Papillae and their Secretions in Annona squamosa L. (Annonaceae). Annals of botany, 1984; 54 (2): 153-168.

[5] Janzen DH and Martin PS. (Neotropical anachronisms: the fruits the gomphotheres ate). Science, 1982; 215 (4528): 1927.

[6] Pandey N and Barve D. Phytochemical and Pharmacological Review on Annona squamosa Linn. International Journal of Research in Pharmaceutical and Biomedical Sciences. 2011; 2 (4): 1404-1412.

[7] Pinto AC, de Q, Cordeiro de Andrade SRM, Ferreira FR, Filgueiras HA, de C, Alves RE and Kinpara DI. Annona species. International Centre for Underutilised Crops, University of Southampton, Southampton, UK. 2005.

[8] Abubakar SM and Aburahman EM. "Useful plants in Control of insect pest." Journal of Herbs, spices and medicinal plants. 1998; 6 (2): 49-54.

[9] Biba VS, Lakshmi S, Dhanya GS and Remani P. Phytochemical analysis of Annona squamosa seed extracts). Int. Res J Pharm. App Sci, 2013; 29-31.

[10] Chang FR, Wu YC and Duh CY. Studies of the acetogenins of Formosan Annonaceous plants. II. Cytotoxic Acetogenins from Annona muricata. Journal of Natural products. 1993; 56 (10): 1688-1694.

[11] Cortes, D, Myint SH, Dupont B and Davaoust D. Bioactive acetogenins from the seeds of Annona cherimola. Phytochemistry. 1993; 32 (6): 1475-1482.

[12] Cassady JM. Natural products as a source of potential cancer chemotherapeutic and chemopreventative agents. Journal of natural products. 1990; 53 (1): 23-41.

[13] Rupprecht JK, Hui YH and McLaughlin JL. Annonaceous acetogenins: a review. J. Nat. Prod. 1990; 53: 237-278.

[14] Igwe AC and Onabanjo AO. Chemotherapeutic effects of Annona senegalensi in Trypanosoma brucei brucei. Ann Trop med parasitol. 1989; 83 (5): 527-534.

[15] Chatterjee A and Pakrashi SC. The Treatise on Indian Medicinal Plants, vol. 1. Council of Scientific \& Industrial Research (India). Publications \& Information Directorate. 1997: 1 .

[16] Yoganarasimhan SN. Medicinal Plants of India. Tamil Nadu. Bangalore: Cyber Media. 2000; 2: 48.

[17] Nadkarni AK. Indian Materia Medica. Mumbai: Popular Prakashan Ltd; 2000; 1: 116.

[18] Owuor BO and Kisangau DP. Kenyan medicinal plants used as antivenin: a comparison of plant usage. Journal of Ethnobiology and Ethnomedicine. 2006. 2: 7.

[19] Kumar R, Roopan SM, Prabhakarn A, Khanna VG and Chakroborty S. Agricultural waste Annona squamosa peel extract: biosynthesis of silver nanoparticles. Spectrochim Acta A Mol Biomol Spectrosc. 2012; 90: 173e6. 
[20] Roopana SM, Bharathi A, Kumar R, Khanna VG, Prabhakarn A. Acaricidal, insecticidal, and larvicidal efficacy of aqueous extract of Annona squamosa $\mathrm{L}$ peel as biomaterial for the reduction of palladium salts into nanoparticles. Colloids Surf B Biointerfaces. 2012; 92: 209e21.

[21] Nandhakumar E and Indumathi P. In vitro Antioxidant Activities of Methanol and Aqueous Extract of Annona squamosa (L.) Fruit Pulp. Journal of Acupuncture and Meridian Studies. 2013; 6 (3): 142-148

[22] Maundu PM, Ngugi GW and Kabuye CHS. Traditional Food plants of Kenya. KENRIK, National museums of Kenya, Nairobi, Kenya. 1999.

[23] Kokwaro JO. Medicinal plants of East Africa. $2^{\text {nd }}$ edition, Kampala, Nairobi, Dares Salam, East Africa Literature Bureau. 1993.

[24] Watt JM and Breyer-Brandwijk GM. The medicinal and poisonous plants of southern and eastern Africa. $2^{\text {nd }}$ Edition London, Livingstone. 1962.

[25] Chimbevo ML, Malala JB, Anjili CO, Orwa J, Mibei EK, Ndeti CM, Muchiri FW, Sifuna PO, Oginga FO, Otundo DO and Karanja SM. Annonaceae Fruits Growing in Coast Region of Kenya as an Alternative Source of Dietary Carotenoids. International Journal of Food Science and Biotechnology. 2017; 2 (5): 114-120.

[26] Babu S, Satish S, Mohan, DC, Raghavendra MP and Raveesha KA. Antibacterial evaluation and phytochemical analysis of some Iranian medicinal plants against plant pathogenic Xanthomonas pathovars. Journal of Agricultural Technology. 2007; 3 (2): 307-316.

[27] Trease GE and Evans WC. Pharmacology, $11^{\text {th }}$ ed. London, Bailliere Tindall Ltd. 1989; 60-75.

[28] Harborne JB. Photochemical methods: A guide to modern techniques of plant analysis London: Chapman A. and Hall. $1973 ; 279$.

[29] Evans WC. Pharmacognosy, $15^{\text {th }}$ ed. London: W. R. Saunders. $2002 ; 137-140$

[30] Edeoga HO, Okwu DE and Mbaebie BO. Phytochemical constituents of some Nigerian medicinal plant. African Journal of Biotechnology. 2005; 4: 685-688.

[31] Sofowara EA. Medicinal plants and traditional medicine in Africa New York: John Wiley and sons. 1982; 1-10.

[32] Trease GE and Evans W. A textbook of pharmacognosy. $15^{\text {th }}$ edition. Academic press, London, 2002; 578.

[33] Spanos GA and Wrolstad RE. Influence of processing and storage on the phenolic composition of Thompson Seedless grape juice. Journal of Agricultural and Food Chemistry. 1990; 38: $1565-1571$.

[34] Kirk RS and Sawyer R. Pearson's composition and analysis of foods. $9^{\text {th }}$ edition, Longman Group Ltd., UK. 1991; 9-197.

[35] AOAC. Official methods of analysis. $17^{\text {th }}$ edition; Gaithersburg, MD, USA, Association of official analytical chemist. 2000.

[36] Ranganna S. Manual of analysis of fruit and vegetable products. Tata MacGraw Hill Company Ltd, New Delhi. 1977; 21-60.
[37] Payne RW, Murray DA, Harding SA, Baird DB and Soutar DM. An introduction to GenStat for Windows, 14th Ed. VSN International, Hemel Hempstead, UK. 2011.

[38] Parry J, Hao Z, Luther M, Su L, Zhou K and Yu L. "Characterization of cold-pressed onion, parsley, cardamom, mullein, roasted pumpkin and milk thistle seed oils", Journal of the American Oil Chemists' Society. 2006; 83 (10): 847 54.

[39] Alawa JN. Effects of three nigerian plants on the histopathology of cutaneous leishmaniasis (Leishmania major) and immunotherapy of leishmaniasis using DNA/protein vaccine in $\mathrm{BALB} / \mathrm{c}$ mice. PhD Thesis, Department of Human Anatomy Faculty of Medicine, Ahmadu Bello University, Zaria, Nigeria. 2008.

[40] Eloff JN. Conservation of Medicinal Plants: Selecting Medicinal Plants for research and gene banking. Monographs in systematic Botany from the Missouri Garden In: Conservation of plants Genes III: Conservation and utilization of African plants. Robert P. Adams and Janice E. Adams, eds., Missouri Botanical Garden Press, St. Louis, USA. 1998; 71: 209-222.

[41] George AP, Broadley R and Nissen R. Preliminary review of the health and medicinal benefits of Annona spp. possible paths to commercialization. A confidential report for the Australian Custard Apple Growers Association. 2006.

[42] Savithramma N, Linga-Rao M and Suhrulatha D. Screening of medicinal plants for secondary metabolites. ME. J. Sci. Res. 2011; 8 (3): 579-584.

[43] Soni H, Sharma S, Patel SS, Mishra K and Singhai AK. Preliminary phytochemical screening and HPLC analysis of flavenoids from methenolic extract of leaves of Annona squamosa. Int. Res. J. Pharma. 2011; 2 (5): 242-246.

[44] Florence AR, Joselin J, Shynin-Brintha TS, Sukumaran S and Jeeva S. Preliminary phytochemical studies of select members of the family Annonaceae for bioactive constituents. Bioscience Discovery. 2014. 5 (1): 85-96.

[45] Akiyama H, Fujii K, Yamasaki O, Oono T and Iwatsuki K. Antibacterial action of several tannins against Staphylococcus aureus. J. Antimirob Chemother. 2001; 48 (4): 487-91.

[46] Etebu E. Differences in Fruit Size, Postharvest Pathology and Phytochemicals between Irvingia gabonensis and Irvingia wombolu. Sustainable Agriculture Research. 2012; 2 (1): 5261.

[47] Onyechi U, Ibeanu U, Nkiruka V, Eme EP and Madubike K. Nutrient Phytochemical Composition and Sensory Evaluation of Soursop (Annona muricata) Pulp and Drink in South Eastern Nigeria. International Journal of Basic and Applied Sciences. 2012; 12 (6): 53-57.

[48] Francis G, Kerem Z, Makkar HP. and Becker K. The biological action of saponins in animal systems: A review. British Journal of Nutrition. 2002; 88: 587-605.

[49] EFSA. Compendium of botanicals that have been reported to contain toxic, addictive, psychotropic or other substances of concern on request of European Food Safety Authority (EFSA). EFSA Journal. 2009; 7 (9): 100.

[50] Onike R. "Phytochemical screening tests and medicinal values of plants active properties". 2010. 
[51] Usunomena U. A Review of some African medicinal plants. International Journal of Pharma and Bio Sciences. 2012; 3 (4): $1-11$.

[52] Dembitsky VM, Poovarodom S, Leontowicz H, Leontowicz M, Vearasilp S, Trakhtenberg S and Gorinstein S. The multiple nutrition properties of some exotic fruits: Biological activity and active metabolites. Food Research International. 2011; 44: $1671-1701$.

[53] Varadharajan V, Janarthanan UK and Krishnamurthy V. Physicochemical, phytochemical screening and profiling of secondary metabolites of Annona squamosa leaf extract. World Journal of Pharmaceutical research. 2012; 1 (4): 11431164.

[54] Valko M, Leibfritz D, Moncol J, Cronin MT, Mazur M and Telser J. Free radicals and antioxidants in normal physiological functions and human disease. The international journal of biochemistry \& cell biology. 2007; 39 (1): 44-84.

[55] Lattanzio V, Lattanzio VMT and Cardinali A. Role of phenolics in the resistance mechanisms of plants against fungal pathogens and insects. Editor: Imperato $\mathrm{F}$. in Phytochemistry: Advances in Research. Research Signpost, Trivandrum, Kerala, India. 2006.

[56] Othman OC, Fabian C. and Lugwisha E. Postharvest physicochemical properties of soursop (Annona muricata L.) fruits of Coast region, Tanzania. J. Food Nutri. Sci. 2014; 2 (5): $220-226$.

[57] Onimawo IA. Proximate composition and selected physicochemical properties of the seed, pulp and oil of soursop (A. muricata). Plant Foods Human Nutr. 2002; 57: 165-171.

[58] Mariod AA, Abdelwahab SI, Elkheir S, Ahmed YM, Fauzi PNM and Chuen CS. Antioxidant activity of different parts from Annona squamosa, and catunaregam nilotica methanolic extract. Acta Sci. Pol., Technol. Aliment. 2012; 11 (3): 249-257.

[59] Lugwisha EH, Fabian C, Othman OC. Postharvest changes in physicochemical properties and level of some inorganic elements of sugar apple (Annona squamosa L.) of coast region Tanzania. Journal of food and Nutrition Science. 2016. 4 (3): 41-48.

[60] Hocking PJ. Dry-matter production, mineral nutrient concentrations, and nutrient distribution and redistribution in irrigated spring wheat. Journal of Plant Nutrition. 1994; 17 (8): 1289-1308.

[61] Appiah F, Oduro I and Ellis WO. Proximate and mineral composition of Artocarpus altilis pulp flour as affected by fermentation. Pakistan Journal of Nutrition. 2011; 10 (7): 653657.

[62] Hussain K, Ismail Z, Sadikun A and Ibrahim P. Proximate and qualitative analysis of different parts of Piper sarmentosum, and quantification of total amides in various extracts. Phcog. Res. 2009; 1: 113-119.

[63] Folorunso AE and Modupe OV. Comparative study on the biochemical properties of the fruits of some Annona species and their leaf architectural study. Not. Bot. Hort. Agrobot. Cluj. 2007; 35 (1): 15-19.

[64] Lim TK. Medicinal and non-medicinal plants. Fruits. 2012.

[65] Pareek S, Yahia EM, Pareek OP and Kaushik RA. Postharvest physiology and technology of Annona fruits. Food Res. Int. 2011; 44: 1741-1751.

[66] Morgan JB and Connolly EL. Plant Soil Interactions in Nutrient Uptake. Nature Education Knowledge. 2013; 4 (8): 2.

[67] Barrette DM, Beaulieu JC and Shewfelt R. Color, Flavor, Texture, and Nutritional Quality of Fresh-Cut Fruits and Vegetables: Desirable Levels, Instrumental and Sensory Measurement, and the Effects of Processing. Critical Reviews in Food Science and Nutrition. 2010; 50: 369-389.

[68] Worrell DBC, Seancarrington C and Hubber DJ. Growth, maturation and ripening of soursop (Annona muricata L.) fruit. Scientia Horticulturae. 1994; 57 (1-2): 7-15.

[69] FAO/WHO. Fruit and Vegetables for Health. Report of a joint FAO/WHO workshop, Kobe, Japan. 2004.

[70] Lozano JE. Chemical composition of fruits and its technological importance: In Fruit Manufacturing. 2006.

[71] Wardlaw GM and Smith AM. Contemporary Nutrition. $7^{\text {th }}$ Edn. McGraw Hill, New York. 2009; 163-199.

[72] Anderson JW, Baird P, Davis RH, Ferreri S, Knudtson M, Koraym A, Waters V and Williams CL. Health benefits of dietary fiber. Nutrition Reviews. 2009; 67 (4): 188-205.

[73] Champ M, Langkilde A, Brouns F, Kettlitz B and Collet YB. Advances in dietary fibre characterization. Definition of dietary fibre, physiological relevance, health benefits and analytical aspects. Nutrition Research Reviews. 2003; 16: 7182 .

[74] Wardlaw T, Salama P, Brocklehurst C, Chopra M and Mason E. Diarrhoea: why children are still dying and what can be done. 2009.

[75] Zimmerman M and Snow ME. Nutrition Basics: An Active Approach. Boston, MA: Flat World. 2018.

[76] Mariod AA, Elkheir S, Ahmed YM and Matthaus B. Annona squamosa and Catunaregam nilotica seeds, the effect of the extraction method on the oil composition. J. Am. Oil Chem. Soc. 2010; 87: 763-769.

[77] Rana VS. Fatty Oil and Fatty Acid Composition of Annona squamosa Linn. Seed Kernels. Biocontrol Science and Technology. 2015; 15 (1).

[78] Bozan B and Temelli F. "Chemical composition and oxidative stability of flax, safflower and poppy seed and seed oils", Bioresource Technology. 2008; 99 (14): 6354-9.

[79] Piombo G, Barouh N, Barea, B, Boulanger R, Brat P, Pina M and Villeneuve P. "Characterization of the seed oils from kiwi (Actinidia chinensis), passion fruit (Passiflora edulis) and guava (Psidium guajava)", Ole agineux. 2006; 13 (2): 195-9.

[80] Hofman, PJ, Vuthapanich, S, Whiley, AW, Klieber A, Simons DH. Tree yield and fruit minerals concentrations influence "Hass" avocado fruit quality. Sci. Hort. 2002; 92: 113-123.

[81] USDA. Agricultural Research Service United States Department of Agriculture National Nutrient Database for Standard Reference. 2009; Release 22.

[82] Mandle VS, Salunke SD, Gaikwad SM, Dande KG and Patil MM. Studies on Nutritional Value of Fruits in Latur District of Maharashtra State (India) with Special Reference to Iron Mineral. J. An. Sci. Adv. 2012; 2 (2): 344-346. 
[83] Daramola AO, Oladimwji MO, Oshodi AA and Popoola AV. Investigation of nutrient composition of selected vegetables and banana samples: In Federal University of Technology, Akure, Institutional repository. 2000.

[84] Choi M, Scholl UI, Yue P, Bjorklund P, Zhao B, NelsonWilliams C, Ji W, Cho Y, Pael A and Men CJ. K+ channel mutations in adrenal aldosterone-producing adenomas and hereditary hypertension. Science. 2011; 331: 768-772.

[85] Straub DA. Calcium supplementation in clinical practice: A review of forms, Doses and indications. Nutr. Clin. Pract. 2007; 22: 286-296.
[86] Marinova D, Ribarova F and Atanassova M. Total phenolic and total flavonoids in Bulgarian fruits and vegetables. Journal of the University of Chemical Technology and Metallurgy. 2005; 40 (3): 255-260.

[87] NRC. Recommended Dietary Allowances. National Research Council. National Academy Press, Washington D. C. USA. 1989.

[88] Boakye AA, Wireko-Manu FD, Agbenorhevi JK and Oduro I. Dietary fibre, ascorbic acid and proximate composition of tropical underutilized fruits. Afr. J. Food Sci. 2014; 8 (6); 305310. 